\title{
Status, distribution, and nesting ecology of Snapping Turtle (Chelydra serpentina) on Cape Breton Island, Nova Scotia, Canada
}

\author{
TERry POWER ${ }^{1, ~}{ }^{*}$ and JoHn GILHEN ${ }^{2}$ \\ ${ }^{1}$ Nova Scotia Department of Natural Resources, 300 Mountain Road, Sydney, Nova Scotia B1L 1A9 Canada \\ ${ }^{2}$ Nova Scotia Museum of Natural History, 1747 Summer Street, Halifax, Nova Scotia B3H 3A6 Canada \\ ${ }^{*}$ Corresponding author: terrance.power@novascotia.ca
}

Power, T., and J. Gilhen. 2018. Status, distribution, and nesting ecology of Snapping Turtle (Chelydra serpentina) on Cape Breton Island, Nova Scotia, Canada. Canadian Field-Naturalist 132(1): 8-17. https://doi.org/10.22621/cfn.v132i1.2042

\begin{abstract}
Based on current knowledge of the ecology and distribution of Snapping Turtle (Chelydra serpentina), both in eastern Canada and elsewhere, we conclude this species is native to Cape Breton Island. Seventy-two reports of Snapping Turtle from Cape Breton (1999-2017) indicate a range centred in the area south of Bras d'Or Lake. Date of oviposition ranged from 19 June to 10 July (median = 26 June) among 26 nests observed during 2012-2014. Clutch size for these nests was 23-65 eggs $($ mean $=46)$ and among 25 protected nests average rate of hatchling emergence was $21.5 \%$. Time from oviposition to emergence of hatchlings $(n=256)$ was $75-120$ days (mean $=87.2 ; \mathrm{SD}=9.0)$ among 20 nests. First emergence ranged from 9 September to 20 October $(75-114$ nest days; mean $=90)$ and last emergence ranged from 13 September to 28 October $(86-120$ nest days; mean $=100)$. Duration of emergence ranged from one day (i.e., synchronous emergence; five nests) to 37 days (mean $=11$ days). The number of days on which hatchlings emerged at a nest ranged from one to nine days (mean $=4$ days). Maximum carapace length was $25.0-31.8 \mathrm{~mm}($ mean $=29.0 \mathrm{~mm})$ and maximum carapace width was $23.5-30.0 \mathrm{~mm}($ mean $=27.0 \mathrm{~mm})$ for 256 hatchlings that emerged from 20 protected nests. Mass of hatchlings was 4.9-9.9 $\mathrm{g}$ (mean $=7.8 \mathrm{~g}$ ).
\end{abstract}

Key words: Snapping Turtle; Chelydra serpentina; status; distribution; nesting ecology; clutch size; hatching success; Cape Breton Island; Nova Scotia; Canada

\section{Introduction}

Snapping Turtle (Chelydra serpentina) is native to mainland Nova Scotia and was first recorded present on Cape Breton Island in 1953 when a large adult was reported from the ocean beach at Port Hood, Inverness County (Bleakney 1958; Gilhen 1984). However, until 1984, Snapping Turtle was known to be present in Cape Breton from only three widely scattered locations that were believed to be the result of released/escaped captive turtles (Gilhen 1984) and this view of the species' status has remained up until the present (COSEWIC 2008; Environment and Climate Change Canada 2016). Our observations, together with reports received from the public by both Nova Scotia Department of Natural Resources (NSDNR) and the Nova Scotia Museum (NSM) within the past two decades, indicate Snapping Turtle is much more widely distributed than earlier believed. Beginning in 1999, detailed investigation of all reports of Snapping Turtle was undertaken to better understand the status and distribution of this species in Cape Breton. On 12 July 2006, we excavated the first documented nest of Snapping Turtle in Cape Breton at Intervale Road, Huntington, Cape Breton County (Gilhen and Power 2018). From 2012 to 2014, we investigated the nesting ecology of this species at this site.

Snapping Turtle was assessed Special Concern by the Committee on the Status of Endangered Wildlife in Canada in 2008 (COSEWIC 2008) and is listed as Special Concern under the Canadian Species at Risk Act in 2011 (SARA Registry 2018) with a proposed Management Plan drafted in 2016 (Environment and Climate Change Canada 2016). Snapping Turtle was listed Vulnerable under the Nova Scotia Endangered Species Act in 2013, but to date, the presence of a naturally occurring population has not been recognized on Cape Breton Island (COSEWIC 2008; Environment and Climate Change Canada 2016). This paper discusses the status of Snapping Turtle on Cape Breton Island, summarizes known distribution based on personal observations as well as records from NSDNR and NSM $(n=$ 75; 1953-2017), and presents data on time of nesting, location of nests, clutch size, time of emergence of hatchlings, survivorship to emergence, and size of hatchlings for nesting areas located at Huntington, Cape Breton County, Nova Scotia.

\section{Study Area}

Cape Breton Island is located off northeastern mainland Nova Scotia, Canada, (approximately. $45.5-47.0^{\circ} \mathrm{N}$, $59.5-61.5^{\circ} \mathrm{W}$ ) separated from the mainland by the Strait of Canso, an approximately $2 \mathrm{~km}$ wide stretch of ocean connecting the Gulf of St. Lawrence to the north with the Atlantic Ocean to the south (Figure 1). A permanent land connection between Cape Breton Island and main- 


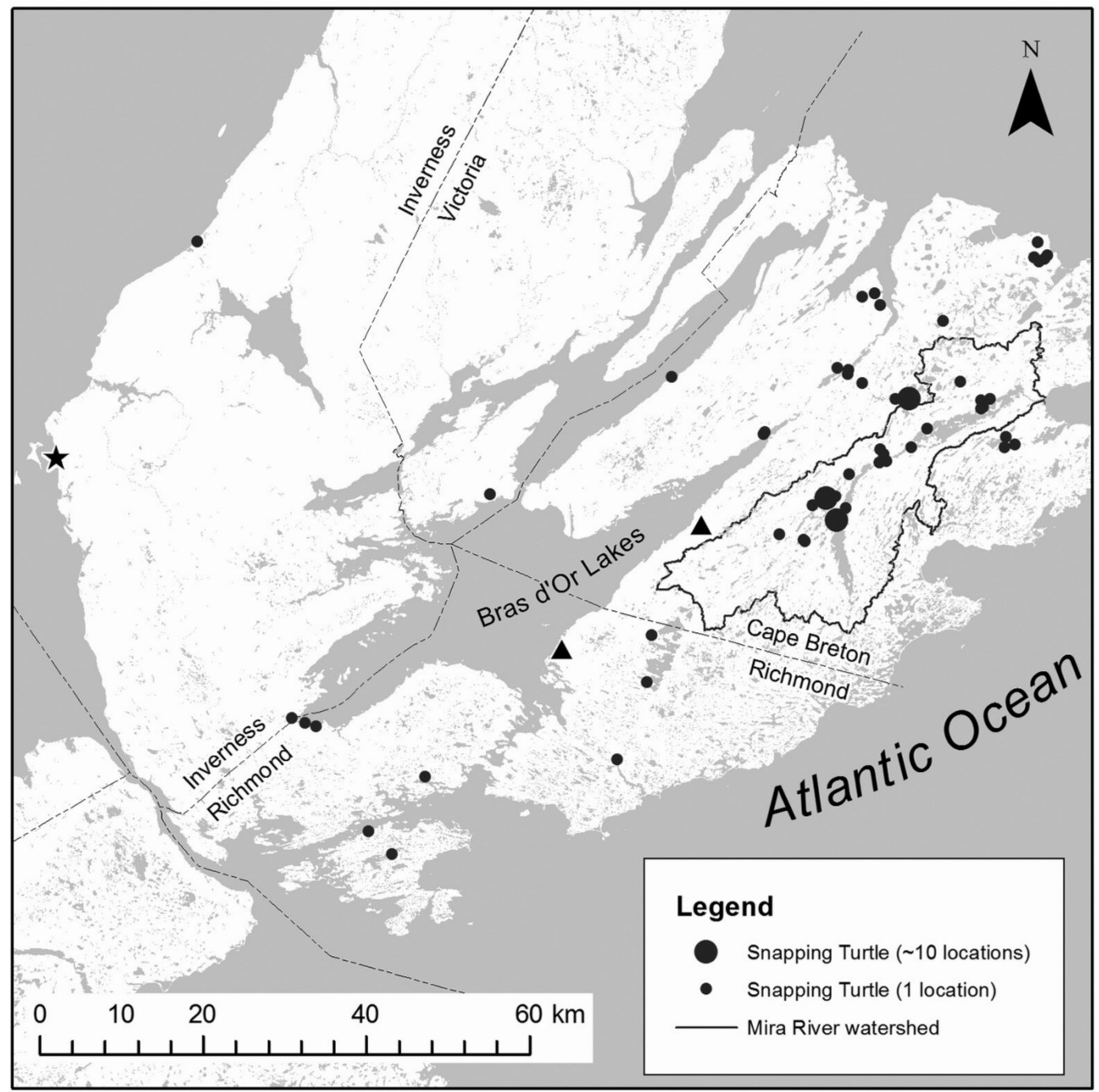

Figure 1. Distribution of records for Snapping Turtle (Chelydra serpentina) on Cape Breton Island, Nova Scotia, Canada 1953-2017 $(n=75)$ including a single record for 1953 (black star; Bleakney 1958; Gilhen 1984), two records for 1977 (black triangles; Gilhen 1984), and 72 records from 1999-2017 (black dots; this study). Contains information licensed under the Open Government License, Nova Scotia.

land Nova Scotia was completed in 1955 with the construction of the Canso Causeway. This narrow connection is a busy thoroughfare and a hostile environment with approaches through industrial lands, affording almost no opportunities for migration of freshwater turtles to or from Cape Breton Island.

\section{Methods}

All reports of Snapping Turtles for Cape Breton Island received from the public by NSDNR and NSM, as well as observations by NSDNR staff, between 1999 and 2017 were investigated and recorded. Interviews, correspondence, photographs, and site visits were used to verify reports and collect accurate location data. Historical records by Bleakney (1958; one record) and Gilhen (1984; three records) were also reviewed. All locations were collated into NSDNR's Biodiversity Investigation Report system and exported to ArcMap GIS (Esri, California, USA) for mapping.

Surveys of known nesting areas at Huntington, Cape Breton County were conducted in June and July 20122014 to determine onset and duration of nesting and to locate nests. Three localized nesting areas were surveyed including two roadside nesting areas and one 
natural riverine nesting area located on a gravel bar (island) in Salmon River near Intervale Road. Surveys were conducted on almost all days in the early part of the nesting season and more opportunistically thereafter. All visible nest attempts were global positioning system mapped and examined to determine if a nest was present. All nests discovered were immediately excavated, eggs were removed and carefully placed in the upright position, counted and returned to the nest in the same upright position, and the nest was re-buried. All nests were covered with $1 \mathrm{~cm}$ mesh galvanized hardware cloth screen fastened to $60 \mathrm{~cm} \times 60 \mathrm{~cm}$ square wooden frames constructed of $38 \times 89 \mathrm{~mm}$ wood and fixed to the ground using $16 \mathrm{~mm}$ rebar stakes, to prevent predation and to retain emerged hatchlings.

Beginning about 70 days after date of oviposition, all nests were surveyed daily to observe emerged hatchlings. Care was taken to replace each nest screen and fasten with rebar stakes to ensure that emerging hatchlings were not able to escape from under the screen undetected. All fully emerged hatchlings (Figure 2) were removed from under the protective screen. Maximum carapace length and width were measured to the nearest $0.1 \mathrm{~mm}$ using calipers, and weight measured to the nearest $0.1 \mathrm{~g}$ using Pesola ${ }^{\circledR}$ spring scales (Medio-Line No. 20010; Baar, Switzerland). Surveys were continued until mid-October 2012 and 2013, and mid-November 2014 and discontinued only after approximately two weeks of no further emergence of hatchlings and onset of cooler temperatures $(2012=17$ days; $2013=15$ days; $2014=13$ days). With one exception, no turtles emerged from a nest after two weeks of no emergence. One or two nests were excavated each year after the emergence period to examine condition of eggs and determine if live hatchlings were still present in the nest. All nest screens were removed for the winter and replaced again in May of the following year to monitor potential spring emergence.

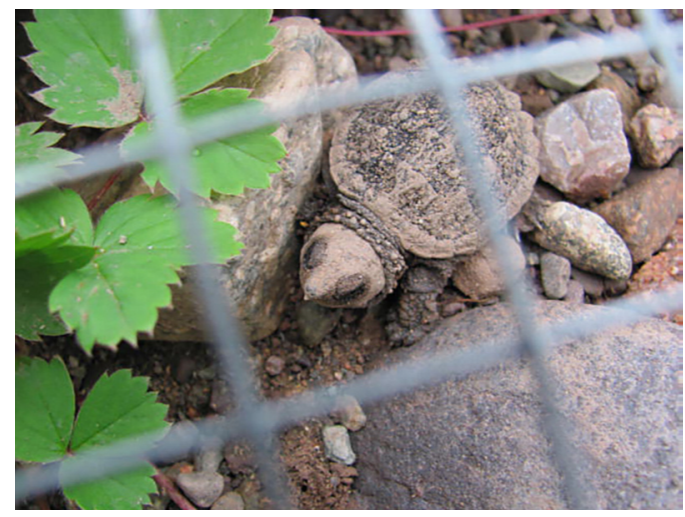

FIGURE 2. Hatchling Snapping Turtle (Chelydra serpentina) emerged from a roadside nest on Intervale Road, Huntington, Cape Breton County, Nova Scotia, Canada, 11 September 2013. Photo: T. Power.

\section{Results}

Between 1999 and 2017 we investigated and verified 72 reports of Snapping Turtle on Cape Breton Island received from both the public and from the observations of NSDNR staff (Table 1). Except for two records for Inverness County (Inverness and West Bay), and one record for Victoria County (Jamesville), all records for Snapping Turtle on Cape Breton Island were in Cape Breton and Richmond Counties. These records indicate a distribution centred on an area of Cape Breton Island south of the Bras d'Or Lakes, with a notable concentration of records from tributaries of Mira River, Cape Breton County (Figure 1). The large number of observers $(n=60)$ submitting reports over an 18-year period and over a wide geographical area suggests there is no significant reporting bias. Within this larger area, many of the records are centred near the confluence of the Salmon River and Mira River and indicate that although Snapping Turtle nests widely across Cape Breton and Richmond Counties, the area of convergence of Salmon and Mira Rivers is the most important known nesting area. Only two records were located on Mira River which is tidal water: one a failed nest attempt and another a turtle carcass, both observed at Juniper Mountain on the southern shore of the Mira River.

Among 72 records of Snapping Turtle, 62 observations were made within the June-July nesting season and many of these were of confirmed (egg-laying observed) or probable (nest attempt without confirmed egg-laying) nesting females (Table 1). Among all records, only two were confirmed juvenile turtles based on carapace growth rings: one observation of a 13-year old turtle at Petersfield Provincial Park in Westmount, Cape Breton County, and one report of a juvenile turtle (estimated 14 years old from photograph) from near Camp Lake, Cape Breton County.

Snapping Turtles in Cape Breton nested in the gravel shoulder of a paved road ( $n=12$ nests), a natural riverine gravel bar ( $n=12$ nests), a semi-vegetated gravel quarry (one nest), and within a child's sandbox (one nest). Other reports of nesting turtles that were investigated $(n=31)$ showed nest attempts and probable nests located in other areas modified by development, including lawns, laneways, a horse paddock, and other areas cleared of vegetation (Table 1). Among 26 Snapping Turtle nests observed during three years (three in $2012 ; 10$ in $2013 ; 13$ in 2014), date of oviposition ranged from 19 June to 10 July (median = 26 June; Table 2). Dates of nesting for those nests monitored ( $n=26)$ were 26-27 June 2012, 19-28 June 2013, and 25 June-10 July 2014. In addition, incidental observations of nesting activity (turtles nesting or making a nest attempt) on Cape Breton Island from 19992017 ( $n=31)$ occurred as early as 17 June 2010 and as late as 26 July 2011 (Table 1). Onset of nesting in each year appeared to be synchronous but the length of the nesting season appeared to vary somewhat from year to year. 


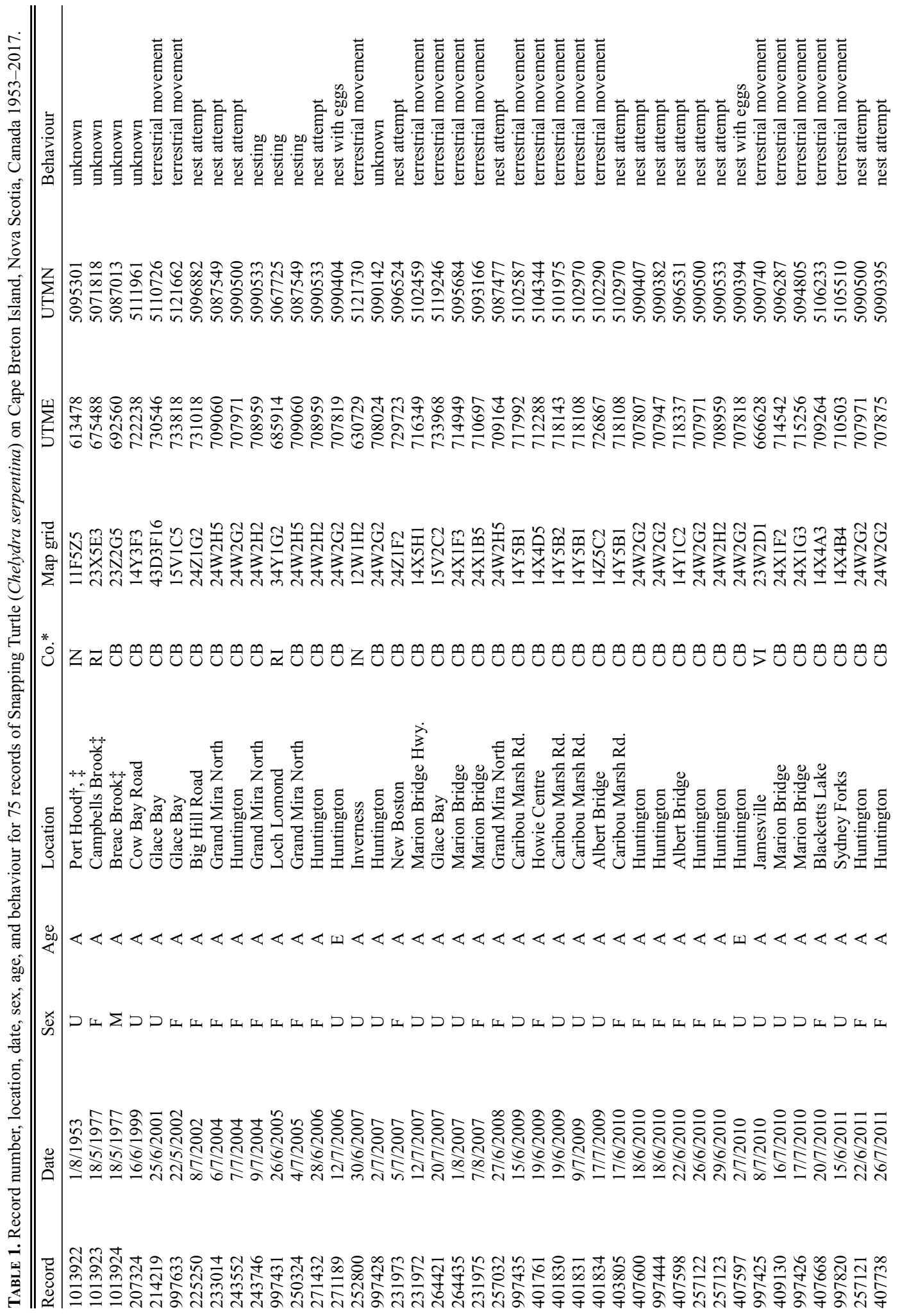




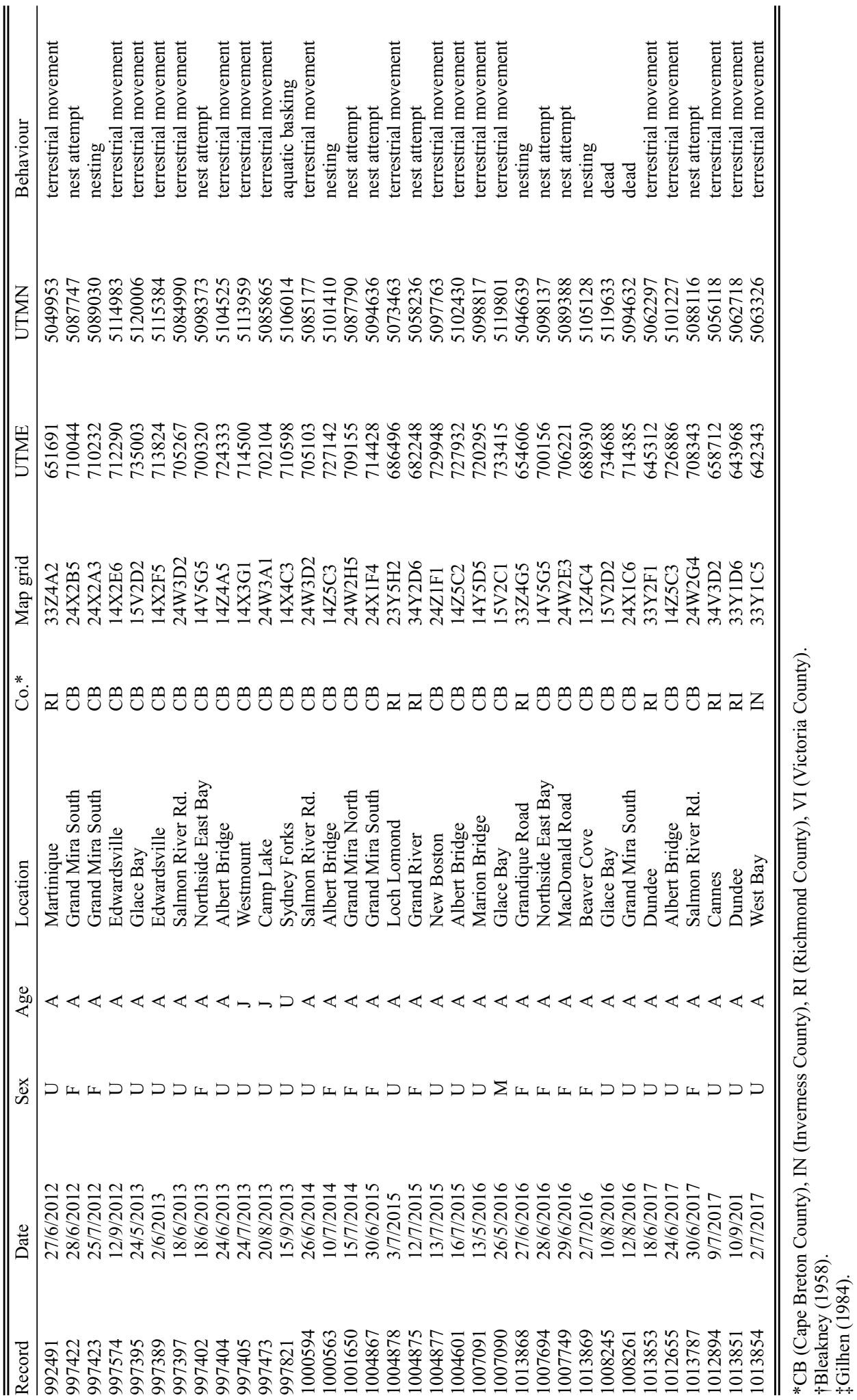




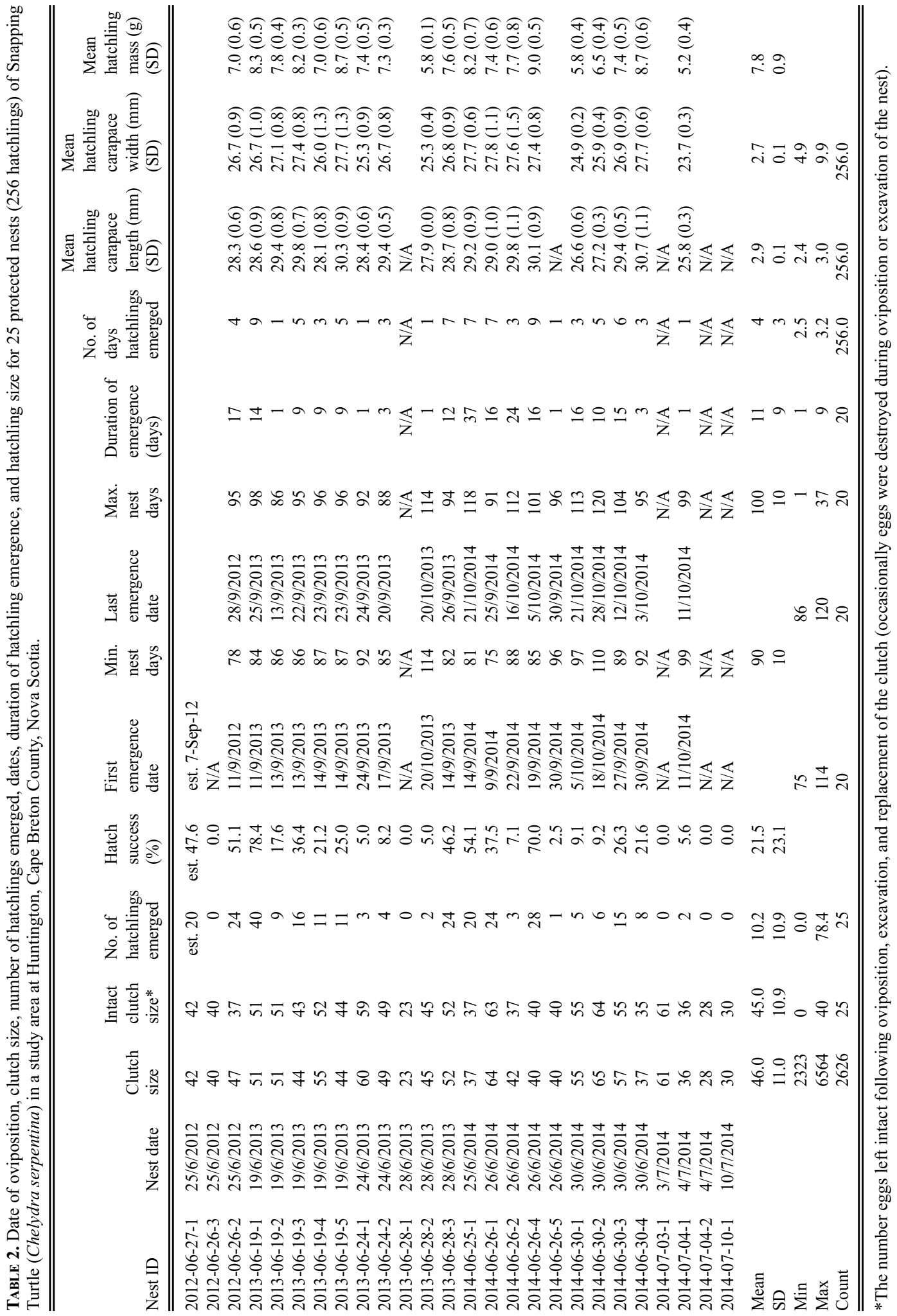


Clutch size for 26 nests protected from predation with wire screen was 23-65 eggs (mean \pm SD: $46 \pm 11$; Table 2). Hatchlings emerged from 20 of 26 protected nests (76.9\%); five nests did not produce hatchlings. An additional riverine nest was flooded during hatchling emergence but appeared to have had partial hatchling emergence. Among the 25 protected nests with a known outcome, the number of hatchlings that emerged ranged from 0 to $40(10 \pm 11)$. The proportion of a clutch that produced emerged hatchlings was $0-78.4 \%$ $(21.5 \pm 23.1)$.

Among 20 protected nests from which hatchlings emerged during 2012-2014, time from oviposition to emergence of a hatchling $(n=256$; Table 2$)$ was 75 120 days $(87.2 \pm 9.0)$. Time of first emergence ranged from 9 September to 20 October (75-114 nest days; $90 \pm 10)$ and date of last emergence ranged from 13 September-28 October $(100 \pm 10)$. Duration of emergence at a nest ranged from one day (i.e., synchronous emergence; five nests) to 37 days for one nest (mean $=10$ days). Among 20 protected nests, number of days on which hatchlings emerged ranged from one to nine $($ mean $=4)$.

A total of 256 hatchlings emerged alive from 20 protected nests (Table 2). An additional one and 12 hatchlings, respectively, were excavated and released alive from two of these nests on 11 October 2013. These 13 hatchlings were initially torpid within the nest due to cool temperatures late in the season but became active once removed from the nest, placed in the sun, and were subsequently released. These hatchlings may not have been able to emerge on their own, had the nest not been excavated. However, the latest date of hatchling emergence in 2013 was 11 days later (20 October) when two hatchlings emerged from one nest.

For 256 hatchlings that emerged from protected nests $(n=20)$, maximum carapace length was $25.0-31.8 \mathrm{~mm}$ $(29.0 \pm 1.2)$ and maximum carapace width was $23.5-$ $30.0 \mathrm{~mm}(27.0 \pm 1.1)$. Mass of hatchlings ranged from 4.9 to $9.9 \mathrm{~g}(7.8 \pm 0.9)$.

\section{Discussion}

Snapping Turtle is native to mainland Nova Scotia (Bleakney 1958; Gilhen 1984) but the occurrence of this species on Cape Breton has been uncertain. Bleakney (1958) provides the first record for Snapping Turtle on Cape Breton Island, that of a large adult reported from the beach at Port Hood, Inverness County in 1953. Gilhen (1984) includes this record and two additional occurrences: one at Campbells Brook, Richmond County and another at Breac Brook, Cape Breton County, both observed on 18 May 1977. These three widely scattered locations were believed to be the result of released/escaped captive turtles (Gilhen 1984) and for 22 years, no further observations were recorded for this species on Cape Breton Island. Beginning in 1999, an effort was made to investigate all sightings received from the public by NSDNR and NSM. In addition,
NSDNR staff were encouraged to actively record sightings. The accumulated reports began to suggest the species was much more widely distributed than earlier believed and several nesting areas were identified.

Seventy-two verified reports of Snapping Turtle on Cape Breton Island from 1999-2017, together with personal observations, indicate a distribution centred on the area of Cape Breton and Richmond Counties south of the Bras d'Or Lakes $\left(45.5-46.0^{\circ} \mathrm{N}\right)$, with a notable concentration of records from tributaries of Mira River, Cape Breton County. Within this larger area, most of the records are centred near the confluence of Salmon River and Mira River. The presence of an important nesting area here, including both riverine and roadside nests, on Salmon River and Intervale Road at Huntington, may largely account for the increased number of reports from this area as Snapping Turtle is highly aquatic, and most reported sightings are of females on land during the nesting season.

The current widespread occurrence and relative abundance of Snapping Turtle on Cape Breton suggests this species is likely native to the Island. The absence of records from 1953 to 1977 and again from 1977 to 1999 is troubling but may simply reflect gaps in searching for and reporting on this species. In this context, Bleakney (1958) discusses similar historical anomalies in documentation of herpetofauna in eastern Canada and elsewhere. The accumulation of reports of Snapping Turtle in Cape Breton since 1999 reflects an effort by the authors to search for reports for this species, to verify all reports received, and to encourage further reporting from observers including both the public and NSDNR staff. Snapping Turtle occurs widely in adjacent mainland Nova Scotia, New Brunswick, and Maine at similar latitudes to that of Cape Breton, so its presence here is not unexpected. Two species of herpetofauna with wide distributions on mainland Nova Scotia which are not native to Cape Breton, are Northern Painted Turtle (Chrysemys picta) and American Bullfrog (Lithobates catesbeianus). In contrast, Wood Turtle (Glyptemys insculpta) is native to both the mainland and Cape Breton Island (Gilhen 1984; Gilhen and Power 2018), even though the presence of this species here was not recognized earlier (Bleakney 1958). Bleakney (1958) discussed the postglacial immigration of amphibians and reptiles into eastern Canada and, based on isostatic land movements and seawater levels, concluded that Cape Breton Island was connected by a land bridge to the adjacent mainland of Nova Scotia between 16000 and 10000 years ago. Gilhen (1984) elaborates on the timing, connection, and isolation of geographic features in the Maritime provinces during the postglacial period and resultant impacts on present distributions of herpetofauna. More recently, Shaw et al. (2002) present evidence, based on isobase maps and a digital terrain model, to show a land connection from Cape Breton Island to mainland Nova Scotia from about 13000-8000 years before present (BP) with peak emer- 
gence of Cape Breton Island at about 9000 years BP. Snapping Turtle is recognized as one of the dominant turtles within North American glacial age faunas and one of the first to invade following glacial retreat at the end of the Wisconsin (Holman and Andrews 1994).

Bleakney (1958) did not recognize the presence of turtles on Cape Breton, even though he reports on a visual sighting of Snapping Turtle by A.W. Cameron at Port Hood Beach, Inverness County in 1953. Bleakney (1958) suggested that turtles may have arrived too late to take advantage of a land bridge to Cape Breton (as well as Prince Edward Island) and presented a range map for the northern limit for freshwater turtles that excludes Cape Breton Island. However, Bleakney (1958) calculated an "Environmental Temperature Index" to estimate the northern limit for Snapping Turtle that includes Cape Breton Island. The approximate northern limit of distribution of Snapping Turtle in Cape Breton $\left(46.0^{\circ} \mathrm{N}\right)$ is well within the range of populations studied elsewhere (e.g., $45.5^{\circ} \mathrm{N}$ in Ontario [Congdon et al. 2008]; $46.0^{\circ} \mathrm{N}$ in Michigan and $47.2^{\circ} \mathrm{N}$ in Minnesota [Ewert et al. 2005]; 53.0 $0^{\circ} \mathrm{N}$ in Manitoba [Holman and Andrews 1994]). The tolerance of Snapping Turtle and its eggs to brackish water conditions, including habitation in coastal saltmarshes (Pope 1961; Kinneary 1992; Klemens 1993; Hunter et al. 1999), would enhance the ability of this species to colonize Cape Breton Island along a prehistoric land bridge with mainland Nova Scotia. Based on current knowledge of the ecology and distribution of Snapping Turtle, both in Eastern Canada and elsewhere, we conclude this species is native to Cape Breton Island and arrived here along with Wood Turtle via a land connection to mainland Nova Scotia about 10000 years BP.

Snapping Turtle is known to nest in a variety of natural and disturbed substrates (Congdon et al. 2008). In Cape Breton, we recorded the species nesting on natural riverine gravel bars as well as a variety of sites modified by development, including gravel road verges, lawns, laneways, a horse paddock, a child's sand box, and other semi-vegetated areas. Turtles here appeared to choose unshaded nest sites, open to the sun, which may reflect an adaptation to hasten embryogenesis in this northern population, as suggested by Ewert et al. (2005). Within its extended range in North America, Snapping Turtle nests earlier in the south than further north (Iverson et al. 1997; Congdon et al. 2008). Warmer springs result in more rapid follicular development and egg maturation, and earlier onset of nesting (Congdon et al. 1987). Date of first observed nesting in Cape Breton (17 June) was somewhat later than in Nebraska (1-12 June; Iverson et al. 1997) and southeastern Michigan (22 May-12 June) where first nesting varied annually by 22 days and was significantly correlated with the amount of heat available in March, April, and May (Congdon et al. 1987). Obbard and Brooks (1987) used accumulation of heat units in a lake to predict onset of nesting and reported that even though date of first nesting in north-central Ontario varied by 15 days over six years, variation in accumulation of heat units varied by only $7.5 \%$. Nesting in Cape Breton (17 June-26 July), also near the northern limit of the species range $\left(46.0^{\circ} \mathrm{N}\right)$, may be somewhat later than that reported for Algonquin Park, Ontario (26 May-7 July; Congdon et al. 2008), at a similar latitude $\left(45.5^{\circ} \mathrm{N}\right)$.

Clutch size of Snapping Turtles in Cape Breton is large but within the range reported from locations elsewhere in the species range (Iverson et al. 1997; Congdon et al. 2008). Clutch size of eight nests at Grafton Lake, Queens County, in southwestern mainland Nova Scotia, was 19-41 eggs (Gilhen 1984). Hatchlings in Cape Breton emerged from $76.9 \%$ of protected nests. Total nest failure (failure of hatchlings to emerge $=$ $19.2 \%$ ) appears higher than reported for southeastern Michigan (egg infertility or failure of embryos to develop $=11.8 \%$; Congdon et al . 1987). Hatching success among protected nests in Cape Breton $(21.5 \%)$ was much lower than in north-central Ontario, at a similar latitude (73.2-85.2\%: Riley and Litzgus 2013). Probability of survival in protected nests in Cape Breton was 0.215 , whereas the probability of survival of unprotected nests (including a 70\% predation rate) was 0.22 in Michigan (Congdon et al. 1987). Nest predation losses in the Michigan population over 17 years averaged $77 \%$ (Congdon et al. 1994). Clearly, the already low survivorship to emergence in protected nests in Cape Breton (comparable to that of unprotected nests in Michigan) would be much further reduced by predation. In nests of Snapping Turtle in Cape Breton, an average of 35 eggs in protected nests failed to produce hatchlings whereas in southeastern Michigan, an average of four eggs or embryos died in nests that escaped predation (Congdon et al. 1987). High nest failure and low hatchling survivorship to emergence, due to factors other than predation, suggest recruitment may be low in this northern population of Snapping Turtle in Cape Breton. Predated nests were observed in Cape Breton during both nesting and hatchling emergence. Often extended duration of emergence at nests in Cape Breton coupled with observed peaks in predation late in incubation elsewhere (Riley and Litzgus 2014) may facilitate increased predation pressure here.

Snapping Turtle in Cape Breton emerged in September and October, and as generally reported elsewhere (Congdon et al. 1987, 2008; Carroll and Ultsch 2007; Baker et al. 2013), no spring emergence was observed. Scattered reports of confirmed (Obbard and Brooks 1981; Parren and Rice 2004) or suspected (Bleakney 1963; Congdon et al. 1987) spring emergence are recorded for this species and have been linked to the insulating effects of unusually deep snow cover (Obbard and Brooks 1981) and an unusually mild winter (Parren and Rice 2004). Snapping Turtle hatchlings in Cape Breton were observed to emerge later (9 September28 October) than reported further south (5-24 Septem- 
ber in New Hampshire [Carroll and Ultsch 2007]; late August to early October in southeastern Michigan [Congdon et al. 1987]). Mean number of days from egg-laying to hatchling emergence in Cape Breton (mean $=87.2$, range $75-120)$ was slightly lower than that reported for north-central Ontario at a similar latitude ( $\sim 93$ days; Riley and Litzgus 2013), and also for Michigan, further to the south (mean $=93.2$, range 73117; Congdon et al. 1987). Mean time to first emergence in Cape Breton was slightly shorter (90 days) than in a more southerly population in Indiana (94 days, range 90-97 days; Baker et al. 2013). Duration of emergence at a nest in Cape Breton, (mean = 11 days) may be longer than reported elsewhere. In Indiana, mean duration of emergence at a nest was eight days (range 1-20 days) and synchronous emergence occurred occasionally (Baker et al. 2013). Synchronous emergence in nests $(25 \%)$ was much lower in Cape Breton than in southeastern Michigan (65\%; Congdon et al. 1987).

Emergence of Snapping Turtle hatchlings in Cape Breton appears to be characterized by a high proportion of asynchronous emergence, a protracted duration of emergence at some nests (up to 37 days) as well as emergence on numerous days within the emergence period. Despite this, however, average time from oviposition to emergence may be shorter in Cape Breton than has been reported elsewhere. Both high and low incubation temperatures compromise survival and growth rates of Snapping Turtle hatchlings (Brooks et al. 1991). Bobyn and Brooks (1994) found that lower incubation temperature increased mortality and compromised growth and survival of hatchling Snapping Turtles and suggest this is an important determinant of the northern limit of this species, through reduced recruitment. Summer temperatures are thought to be the dominant factor limiting the northern distribution of herpertofauna in Canada (Bleakney 1958; Brooks 2007) and Snapping Turtle approaches the northern limit of its range in Cape Breton.

The relatively large and deep nests of Snapping Turtles likely contribute to the observed temperature differences within nests with depth which has been reported (Packard et al. 1985). Packard et al. (1987, 1998, 1999) discuss the importance of variation in thermal and to a lesser extent, hydric, conditions of incubating eggs of Snapping Turtle to both size and physiological condition of hatchlings. The high proportion of asynchronous emergence and extended duration of emergence for individual nests in Cape Breton may reflect differing hydric and, especially, temperature conditions within nests, exaggerated by already marginal incubation conditions experienced by this northern population.

Size of Snapping Turtle hatchlings in Cape Breton ( $n=256$; mean carapace length $=29.0 \mathrm{~mm}$, range 25.0 $31.8 \mathrm{~mm}$; mean carapace width $=27.0 \mathrm{~mm}$, range 23.5 $30.0 \mathrm{~mm}$; mean mass $=7.8 \mathrm{~g}$, range $4.9-9.9 \mathrm{~g}$ ) was similar to that of hatchlings in southeastern Michigan (mean carapace length $=29.1 \mathrm{~mm}$, range $23.0-33.0 \mathrm{~mm}$; mean mass $=8.9 \mathrm{~g}$, range $5.0-11.0 \mathrm{~g}$; Congdon et al. 1987) and north-central Ontario (carapace length $=27.84 \mathrm{~mm}$ [males] and $29.47 \mathrm{~mm}$ [females]; mean mass $=9.03 \mathrm{~g}$ [males] and $9.68 \mathrm{~g}$ [females]; Riley et al. 2014). Within nests in Cape Breton, size of emerged hatchlings appears to decrease with both clutch size and date of hatchling emergence but further exploration of this relationship is needed.

\section{Acknowledgements}

Funding was provided by NSDNR. Bill English and Mark Pulsifer, NSDNR, provided support for this work. Doug Orr, Ravin Randhawa, and Taylor Cochrane, NSDNR, provided invaluable assistance with the NSDNR Biodiversity Investigation Report data for Snapping Turtle. Tracy Lenfesty, Head Librarian, NSDNR, generously assisted with compilation of literature on Snapping Turtle. Nick Deagle, NSDNR, created the map for Figure 1. We thank the editor and two anonymous reviewers for helpful comments on this manuscript. We are indebted to all those people who contributed observations of Snapping Turtles in Cape Breton. This paper is dedicated to the memory of John Mercer ('Big-Bird'), long-serving Technician, Forest Resources, with NSDNR.

\section{Literature Cited}

Baker, P.J., J.P. Costanzo, J.B. Iverson, and R.E. Lee, Jr. 2013. Seasonality and interspecific and intraspecific asynchrony in emergence from the nest by hatchling freshwater turtles. Canadian Journal of Zoology 91: 451-461. https:// doi.org/10.1139/cjz-2012-0335

Bleakney, J.S. 1958. A zoogeographical study of the amphibians and reptiles of eastern Canada. Bulletin 155. National Museum of Canada. Department of Northern Affairs and National Resources, Ottawa, Ontario, Canada.

Bleakney, J.S. 1963. Notes on the distribution and life histories of turtles in Nova Scotia. Canadian Field-Naturalist 77: 67-76. Accessed 22 July 2018. https://biodiversitylibrary. org/page/28098840.

Bobyn, M.L., and R.J. Brooks. 1994. Incubation conditions as potential factors limiting the northern distribution of snapping turtles, Chelydra serpentina. Canadian Journal of Zoology 72: 28-37. https://doi.org/10.1139/z94-005

Brooks, R.J. 2007. Do reptiles in Canada have a future? An overview of the constraints on conserving Canadian snakes, turtles, and lizards. Pages 183-190 in Ecology, Conservation, and Status of Reptiles in Canada. Edited by C.N.L. Seburn and C.A. Bishop. Herpetological Conservation Series Number Two, Society for the Study of Amphibians and Reptiles, Salt Lake City, Utah, USA.

Brooks, R.J., M.L. Bobyn, D.A. Galbraith, J.A. Layfield, and E.G. Nancekivell. 1991. Maternal and environmental influences on growth and survival of embryonic and hatchling Snapping Turtles (Chelydra serpentina). Canadian Journal of Zoology 69: 2667-2676. https://doi.org/10.1139/ z91-375

Carroll, D.M., and G.R. Ultsch. 2007. Emergence season and survival in the nest of hatchling turtles in southcentral New Hampshire. Northeastern Naturalist 14: 307-310. https://doi.org/10.1656/1092-6194(2007)14[307:ESASIT] 2.0.CO;2 
Congdon, J.D., G.L. Breitenbach, R.C. van Loben Sels, and D.W. Tinkle. 1987. Reproduction and nesting ecology of Snapping Turtles (Chelydra serpentina) in southeastern Michigan. Herpetologica 43: 39-54.

Congdon, J.D., A.E. Dunham, and R.C. van Lobeb Sels. 1994. Demographics of Common Snapping Turtles (Chelydra serpentina): implications for conservation and management of long-lived organisms. American Zoologist 34: 397-408. https://doi.org/10.1093/icb/34.3.397

Congdon, J.D., J.L. Green, and R.J. Brooks. 2008. Reproductive and nesting ecology of female Snapping Turtles. Pages 123-134 in The Biology of the Snapping Turtle. Edited by A.C. Steyermark, M.S. Finkler, and R.J. Brooks. Hopkins University Press, Baltimore, Maryland, USA.

COSEWIC (Committee on the Status of Endangered Wildlife in Canada). 2008. COSEWIC assessment and status report on the Snapping Turtle Chelydra serpentina in Canada. COSEWIC, Ottawa, Ontario, Canada. Accessed 8 January 2018. http://sararegistry.gc.ca/virtual_sara/files/ cosewic/sr snapping turtle 0809 e.pdf.

Environment and Climate Change $\bar{C}$ anada. 2016. Management plan for the Snapping Turtle (Chelydra serpentina) in Canada [Proposed]. Species at Risk Act Management Plan Series. Environment and Climate Change Canada, Ottawa, Ontario, Canada. Accessed 8 January 2018. https://www. registrelep-sararegistry.gc.ca/virtual_sara/files/plans/mp_ snapping\%20turtle_e_proposed.pdf.

Ewert, M.A., J.W. Lang, and C.E. Nelson. 2005. Geographic variation in the pattern of temperature-dependent sex determination in the American Snapping Turtle (Chelydra serpentina). Journal of Zoology 265: 81-95. https://doi. org/10.1017/S0952836904006120

Gilhen, J. 1984. Amphibians and Reptiles of Nova Scotia. Nova Scotia Museum. Province of Nova Scotia, Halifax, Nova Scotia, Canada.

Gilhen, J., and T. Power. 2018. Snapping Turtle-Tortue serpentine - turtle mi' kjikj (snapping; Chelydra serpentina) added to the herpetofauna of Cape Breton Island, Nova Scotia, Canada. Canadian Field-Naturalist 132: 4-7. https:// doi.org/10.22621/cfn.v132i1.2020

Holman, J.A., and K.D. Andrews. 1994. North American quaternary cold-tolerant turtles: distributional adaptations and constraints. Boreas 23: 44-52. https://doi.org/10.1111/ j.1502-3885.1994.tb00585.x

Hunter, J.L., Jr., A.J.K. Calhoun, and M. McCollough. 1999. Maine Amphibians and Reptiles. University of Maine Press, Orono, Maine, USA.

Iverson, J.B., H. Higgins, A. Sirulnik, and C. Griffiths. 1997. Local and geographic variation in the reproductive biology of the Snapping Turtle (Chelydra serpentina). Herpetologica 53: 96-117.

Kinneary, J.K. 1992. The effect of water salinity on growth and oxygen consumption of Snapping Turtle (Chelydra serpentina) hatchlings from an estuarine habitat. Journal of Herpetology 26: 461-467. https://doi.org/10.2307/156 5124

Klemens, M.W. 1993. Amphibians and reptiles of Connecticut and adjacent regions. State geological and natural history survey of Connecticut. Bulletin 112. Connecticut Depart- ment of Environmental Protection, Hartford, Connecticut, USA.

Obbard, M.E., and R.J. Brooks. 1981. Fate of overwintered clutches of the Common Snapping Turtle (Chelydra serpentina) in Algonquin Park, Ontario. Canadian Field-Naturalist 95: 350-352. Accessed 22 July 2018. https://biodi versitylibrary.org/page/28062053.

Obbard, M.E., and R.J. Brooks. 1987. Prediction of the onset of the annual nesting season of the Common Snapping Turtle. Herpetologica 43: 324-328.

Packard, G.C., K. Miller, M.J. Packard, and G.F. Birchard. 1999. Environmentally induced variation in body size and condition in hatchling snapping turtles (Chelydra serpentina). Canadian Journal of Zoology 77: 278-289. https://doi.org/10.1139/z98-217

Packard, G.C., M.J. Packard, K. Miller, and T.J. Boardman. 1987. Influence of moisture, temperature and substrate on snapping turtle eggs and embryos. Ecology 68: 983-993. https://doi.org/10.2307/1938369

Packard, G.C., M.J. Packard, K. Miller, and T.J. Boardman. 1998. Effects of temperature and moisture during incubation on carcass composition of hatchling snapping turtles (Chelydra serpentina). Journal of Comparative Physiology B 158: 117-125. https://doi.org/10.1007/BF 00692735

Packard, G.C., G.L. Paukstis, T.J. Boardman, and W.H.N. Gutzke. 1985. Daily and seasonal variation in hydric conditions and temperature inside nests of common snapping turtles (Chelydra serpentina). Canadian Journal of Zoology 63: 2422-2429. https://doi.org/10.1139/z85-358

Parren, S.G., and M.A. Rice. 2004. Terrestrial overwintering of hatchling turtles in Vermont nests. Northeastern Naturalist 11: 229-233. https://doi.org/10.1656/1092-6194(2004) 011[0229:TOOHTI]2.0.CO;2

Pope, C.H. 1961. Turtles of the United States and Canada. Alfred A. Knopf, New York, New York, USA.

Riley, J.L., S. Freedberg, and J.D. Litzgus. 2014. Incubation temperature in the wild influences hatchling phenotype of two freshwater turtle species. Evolutionary Ecology Research 16: 397-416.

Riley, J.L., and J.D. Litzgus. 2013. Evaluation of predatorexclusion cages used in turtle conservation: cost analysis and effects on nest environment and proxies of hatchling fitness. Wildlife Research 40: 499-511. https://doi.org/10. 1071/WR13090

Riley, J.L., and J.D. Litzgus. 2014. Cues used by predators to detect freshwater turtle nests may persist late into incubation. Canadian Field-Naturalist 128: 179-188. https: //doi.org/10.22621/cfn.v128i2.1583

SARA (Species at Risk Act) Registry. 2018. Species profile, Snapping Turtle. Government of Canada. Accessed 16 May 2018. http://sararegistry.gc.ca/species/speciesDetails_e.cfm ?sid=1033\#ot 18 .

Shaw, J., P. Gareau, and R.C. Courtney. 2002. Paleogeography of Atlantic Canada 13-0 kyr. Quaternary Science Reviews 21: 1861-1878. https://doi.org/10.1016/S0277-37 91(02)00004-5

Received 2 February 2018

Accepted 11 April 2018 